\title{
Correction to: Atmospheric blocking events in the North Atlantic: trends and links to climate anomalies and teleconnections
}

\author{
Hussein Wazneh ${ }^{1,2,3}$ (1) Philippe Gachon ${ }^{1,3} \cdot$ René Laprise $^{2,3} \cdot$ Anne de Vernal $^{2,3} \cdot$ Bruno Tremblay $^{4}$
}

Published online: 8 February 2021

(c) The Author(s) 2021

\section{Correction to: Climate Dynamics \\ https://doi.org/10.1007/s00382-020-05583-x}

The article: Atmospheric blocking events in the North Atlantic: trends and links to climate anomalies and teleconnections, written by Hussein Wazneh, Philippe Gachon, René Laprise, Anne de Vernal, Bruno Tremblay was originally published electronically on the publisher's internet portal (currently SpringerLink) on 5 January 2021 without open access.

With the author(s)' decision to opt for Open Choice the copyright of the article changed on 15 February 2021 (c) The Author(s) 2021 and the article is forthwith distributed under the terms of the Creative Commons Attribution 4.0 International License (http://creativecommons.org/licenses/ by/4.0/), which permits use, duplication, adaptation, distribution and reproduction in any medium or format, as long as you give appropriate credit to the original author(s) and the source, provide a link to the Creative Commons license and indicate if changes were made.

Open Access This article is distributed under the terms of the Creative Commons Attribution 4.0 International License

The original article can be found online at https://doi.org/10.1007/ s00382-020-05583-x.

Hussein Wazneh

wazneh.hussein@uqam.ca

1 Department of Geography, University of Québec at Montréal (UQAM), Québec, Canada

2 Department of Earth and Atmospheric Sciences, University of Québec at Montréal (UQAM), Québec, Canada

3 ESCER (Étude et Simulation du Climat à l'Échelle Régionale) Centre, University of Québec at Montréal (UQAM), Québec, Canada

4 Department of Atmospheric and Oceanic Sciences, McGill University, Québec, Canada (http://creativecommons.org/licenses/by/4.0/), which permits unrestricted use, distribution, and reproduction in any medium, provided you give appropriate credit to the original author(s) and the source, provide a link to the Creative Commons license, and indicate if changes were made.

The original article was corrected.

Publisher's Note Springer Nature remains neutral with regard to jurisdictional claims in published maps and institutional affiliations. 